\section{Territorializar la arquitectura}

\author{
José Rosas, Decano Facultad de Arquitectura, Diseño y Estudios Urbanos, \\ Pontificia Universidad Católica de Chile
}

La puesta en valor del papel de la arquitectura en la conformación del territorio, ya sea como trozo o fragmento de una extensión mayor, o bien, como representación de un detalle del mismo, son algunas de las temáticas que convergen en la reflexión propuesta por el autor de las lecturas que acompañan a este número.

MEDIACIONES, INTERACCIONES, TRANSICIONES Y ESTRATIFICACIONES EN LA CONSTRUCCIÓN DEL ENTORNo / Gran parte del esfuerzo de los cuatro artículos que a continuación se presentan, está centrado en el papel del territorio en la arquitectura, o más precisamente, cómo desde distintos flancos problematizan la territorialización de la arquitectura para entender la relación entre el medio construido y modificado por el hombre, que manifiestan los distintos agentes sociales en un determinado entorno.

En el campo de intervención específico del arquitecto, estos planteamientos permiten, por una parte, construir una reflexión sobre la realidad arquitectónica en toda su complejidad así como, por la otra, recuperan la dimensión que un determinado soporte espacial establece en el marco de unas relaciones críticas entre la arquitectura y las estrategias de construcción del paisaje.

El territorio en este contexto es, en realidad, la manifestación profunda de una estructura de ocupación del suelo con sus consecuentes lógicas de distribución de infraestructuras y tipologías edificatorias que un asentamiento humano, cargado de historias e imaginarios, proyecta sobre una determinada realidad física.

Como acertadamente nos lo propuso Ignasi de Solà-Morales, la noción de territorio, "no sólo es el sistema de espacios habitables con su determinación topográfica, histórica y social; también como el punto de partida, el lugar de encuentro de la actividad formativa, que es al mismo tiempo la arquitectura y la ciudad en cualquier sentido que podamos dar a estos términos". De este modo, el proyecto de una nueva edificación empieza a ser entendido, más allá de su condición objetual, particular e individual, como un espacio de mediación, interacción, transición y estratificación del entorno en que el hombre vive y se manifiesta. En efecto, el territorio es parte co-sustancial de la arquitectura, forma parte de ella, la constituye y también, la materializa.

Creo que si estos trabajos que se presentan tienen algo en común es, el énfasis que ponen en un modo de sensibilizar y situar la tarea del arquitecto, y de las disciplinas que participan en su definición, allí en el terreno real en que la obra construida se experimenta y posibilita, y dónde es parte constitutiva de un debate amplio sobre la sociedad a la que intenta transformar. Estamos frente a unos trabajos que nos revelan la existencia de unos campos más densos acerca del rol del entorno en la arquitectura y al mismo tiempo sugieren -en el contexto de unas operaciones de proyecto que se presentan ligadas a un mundo globalizado e interconectado a una red de relaciones, y en una sociedad compleja que manifiesta significativas transformaciones y enormes desafíos e incertidumbres en sus futuros desarrollos- como una tarea ineludible de los arquitectos contemporáneos, el replantearse el rol que este ejerce frente a las demandas que el contexto y sus circunstancias plantean.

Es más, si asumimos que en estas últimas décadas, cualquier tema de la contemporaneidad ha exigido a académicos y profesionales del diseño, arquitectura y urbanismo, unos giros vitales e importantes precisiones en los modos de operar en relación a lo ya dado con el territorio que interfiere, es necesario reconocer que las cuestiones de fondo y las preguntas significativas que hoy en día se ha de plantear nuestra actividad proyectual, se encuentran bastante alejadas de los paradigmas formales y figurativos que nos dominaron durante el s. XX, pero es justo reconocer que estamos mucho más cerca de la realidad en que la arquitectura se inscribe como una parte del paisaje modificado, y es entendida como un detalle del territorio. ARQ

\section{Territorializing architecture}

José Rosas, Dean of the School of Architecture, Design and Urban Studies. Pontificia Universidad Católica de Chile

Putting the value of architecture in the composition of a territory, be it a piece or fragment of a larger area or a representation of one detail, is one of the subjects that converge in the proposed reflection of the articles in this edition.

MEDIATIONS, INTERACTIONS, TRANSITIONS AND STRATIFICATIONS IN THE CONSTRUCTION OF THE SETTING / The aim of the four articles presented below is centered, to a great extent, on the role of territory in architecture, or more precisely, how they propose, from different problematic flanks, the territorialization of architecture as an appropriate conceptual framework for understanding the relationship between the medium constructed and modified by man manifested by the different social players of a specific setting.

In the field of specific intervention by the architect, such arguments allow, on the one hand, for a reflection on the full complexity of the architectural reality, and on the other hand, a dimension to be recovered that is established by a specific spatial support within the framework of critical relationships between architecture and the strategies of landscape construction.

Territory in this context is, in fact, the profound expression of land use with its resulting logic of distribution of infrastructures and building types that a human settlement, imbued with stories and imagination, projects onto a certain physical reality.

As Ignasi de Solà-Morales quite rightly stated, the notion of territory "is not only the system of habitable spaces with its topographical, historical and social specification, but also the starting point, the meeting place of formative activity, which is, at the same time, architecture and the city in any meaning that we may give to these terms". Thus, the design of a new building begins to be understood, beyond its objective, particular and individual condition, as a space of mediation, interaction, transaction and stratification of the environment in which mankind lives and expresses himself. In fact, territory is a consubstantial part of architecture, is part of it, constitutes it and also materializes it.

I believe that if there is any common denominator in these works presented, it is the emphasis that they place on a form of sensitizing and directing the task of the architect and the disciplines that are entailed in its definition, on the real site where the work will and can be built and where it constitutes part of an ample debate on the society that it is attempting to transform.

We are in the presence of works that reveal the existence of denser fields regarding the role of the setting in architecture and at the same time suggest -within the context of design operations that are linked to a globalized world and interconnected to a network of relationships, and in a complex society that reflects significant transformations and enormous challenges and uncertainties in its future development- that an unavoidable task of contemporary architects should be to reconsider the role it plays in the face of requirements posed by the context and its circumstances.

Furthermore, if we assume that in these past few decades any contemporary subject has demanded vital adjustments and important precisions from design, architecture and urbanism academics and professionals in the ways in which territory has been handled and intervened, we must admit that the in-depth matters and significant questions that our designers must ask are very far removed from the formal and figurative paradigms that dominated us during the $20^{\text {th }}$ century. Yet it is only fair to acknowledge that we are much closer to that reality in which architecture becomes a part of the modified landscape and is understood to be one element of the territory. ARa 